\title{
MODE OF ANTAGONISTIC ACTION OF LEVALLORPHAN IN MORPHINE-DEPENDENT RATS AND ASSESSMENT OF PHYSICAL DEPENDENCE LIABILITY
}

\author{
Eijiro TAGASHIRA, Tomoko IZUMI and Saizo YANAURA \\ Department of Pharmacology, Hoshi College of Pharmacy, \\ Ebara, Shinagawa-ku, Tokyo 142, Japan
}

Accepted April 4, 1979

\begin{abstract}
The antagonistic mode of levallorphan in rats dependent on morphine or codeine was studied from the viewpoints of the doses of morphine and the lengths of administration and also from the standpoint of timing of the challenge. In morphinedependent rats on morphine-admixed food $(60-100 \mathrm{mg} / \mathrm{kg} /$ day $)$ for 1,3 and 6 weeks, the rate of maximum weight loss on application of levallorphan $(2 \mathrm{mg} / \mathrm{kg}$, s.c. $)$ did not correlate with the length of morphine treatment. The rate of weight loss on single application of levallorphan $0,6,12$ or 24 hours after withdrawal of morphine was lower with the passage of time after the withdrawal. Rats which were given levallorphan 3 times in succession, i.e., at 0,5 and 10 hours after morphine withdrawal showed such a pattern of weight loss that the first application of levallorphan resulted in $7 \%$ loss, while with the second and third applications there was little weight loss. Despite the continued withdrawal, the animals began to gain body weight as early as 14 hour, and body weight was totally recovered before the withdrawal in 24 hour. In conclusion, it is advisable to challenge with levallorphan at 0 hour of withdrawal to obtain qualitative and reproducible results. In addition, the application of levallorphan to morphinedependent rats at adequate intervals provides for the early recovery of abstinence signs.
\end{abstract}

There is a considerable accumulation of data on the physical dependence of rats on morphine-type drugs and narcotic antagonists. Hosoya (1) reported that the challenge with nalorphine at each stage in the subcutaneous application of gradedly increased doses (20$100 \mathrm{mg} / \mathrm{kg}$ ) of morphine to rats induced the well-known signs of morphine abstinence, e.g., loss in body weight, hypothermia, piloerection, soft feces, etc. Way et al. (2), Wei and Loh (3) and Wei (4) studied the abstinence signs by giving subcutaneous application of naloxone to mice and rats both made dependent on morphine by the newly developed morphine pellet implantation method, chiefly in terms of the dose-response relationship, and they also investigated the mode of antagonism by naloxone. Besides these studies on small animals, investigation has also been made on the abstinence signs and drug dependence by challenging with narcotic antagonists to drug-dependent dogs $(5,6)$ and monkeys (7). In these studies, however, the method for quantitative determination or evaluation of physical dependence liability to morphine-type drugs, using narcotic antagonists was not established. Therefore, we did quantitative studies on the abstinence signs evolving around application of levallorphan to rats made dependent on morphine and those made dependent on codeine

Footnote: Part of this data was reported at the International Narcotic Research Conference, July 23-27, 1978, Noordwijkerhout, The Netherlands. 
by the Drug-Admixed Food (DAF) method we have developed, and we investigated the roles in narcotic dependence tests and the limitations thereof. The modes of antagonistic actions of levallorphan were discussed by comparing the evolving patterns of abstinence signs induced by forcing animals to ingest morphine or codeine consecutively by the DAF method with those induced by the challenge with levallorphan.

\section{MATERIALS AND METHODS}

Male Sprague-Dawley rats (reproduced at the Japan CLEA, Tokyo) were purchased at the age of 4 weeks, and only those which showed normal weight gains and food consumption during the one-week taming period were used. Morphine-dependent rats were produced by two ways of application of morphine and codeine: (1) the drug-admixed food method (DAF method) allowing animals to eat food containing 0.5 - and $1-\mathrm{mg}$ of morphine per $\mathrm{g}$ of food and food containing $1-$ and $2-\mathrm{mg} / \mathrm{g}$ ad libitum; and (2) the parenteral application of morphine in gradedly increased doses from $20-100 \mathrm{mg} / \mathrm{kg}$ s.c. twice daily (09:00 and 17:00 hr).

The rats made dependent on morphine or codeine by the above mentioned methods of application were challenged with the narcotic antagonist, levallorphan. Levallorphan is most commonly used in Japan as a narcotic antagonist in physical dependence liability tests, and is potent enough to precipitate withdrawal signs in rats dependent on morphine or codeine. Experiment 1: The animals made dependent on morphine by ingestion of morphine $(0.5-$ and $1-\mathrm{mg} / \mathrm{g}$ food) for 3 weeks were challenged with $0.1,0.3,1.0,3.0$ and $10 \mathrm{mg} / \mathrm{kg}$ s.c. of levallorphan under conditions where the morphine was not withdrawn (at $0 \mathrm{hr}$ of withdrawal). Variations in body weight with the application of levallorphan were measured during the following $24 \mathrm{hr}$ in order to obtain the maximum weight loss rate and the dose-response curve of levallorphan. The signs of abstinence from morphine evolving on application of the antagonist were also observed. Experiment 2: morphine and codeine were applied in two dosage levels: $0.5-$ and $1-\mathrm{mg} / \mathrm{g}$ food, and $1-$ and $2-\mathrm{mg} / \mathrm{g}$ food. The animals were challenged with 2 or $5 \mathrm{mg} / \mathrm{kg}$ s.c. of levallorphan at 1,3 and 6 weeks of feeding on either food, in order to study the correlation between the doses and application periods of morphine and the severity of the abstinence signs induced by levallorphan. Experiment 3: Variations in body weight of animals with the application of levallorphan $(17: 00 \mathrm{hr})$ on the final day at each of the gradedly increased subcutaneous doses of 20,60, 80 and $100 \mathrm{mg} / \mathrm{kg}$ of morphine (twice a day) were observed, and the results from rats made dependent on morphine by DAF method were compared (Exp. 2). Experiment 4: Levallorphan was given to rats made dependent on morphine by the DAF method (0.5- and 1$\mathrm{mg} / \mathrm{g}$ food) at different stages after withdrawal of morphine, i.e., 6, 12 and $24 \mathrm{hr}$ after replacing the morphine-admixed food with the usual animal food. Experiment 5: Morphine-dependent rats ingesting morphine $(0.5-$ and $1-\mathrm{mg} / \mathrm{g}$ food) for 3 weeks were each given levallorphan ( $2 \mathrm{mg} / \mathrm{kg}$, s.c.) 3 times in succession at $5 \mathrm{hr}$ intervals, i.e., 0,5 and $10 \mathrm{hr}$ after withdrawal of morphine to observe variations in body weight and abstinence signs at specified intervals. 


\section{RESULTS}

Experiment 1: When levallorphan $(0.1-10 \mathrm{mg} / \mathrm{kg}$, s.c.) was challenged to morphinedependent and non-withdrawn rats, abstinence signs and variations in body weight were observed during the following $24 \mathrm{hr}$; and the maximum weight loss rate and dose response curve is shown in Fig. 1. The application of either dose of levallorphan was followed in 15-30 min by the evolvement of morphine abstinence signs, e.g., soft feces or diarrhea, piloerection and wet dog phenomena and also by abrupt weight loss. The maximum loss in body weight occurred 4-5 hr after the application of levallorphan. There was an almost linear relationship between the doses of levallorphan and the maximum weight loss rates within the doses applied.

Experiment 2: Fig. 2 shows the maximum weight loss rate with the application of 2 and $5 \mathrm{mg} / \mathrm{kg}$ s.c. of levallorphan to the animals made dependent slightly and strongly on morphine or codeine at $0 \mathrm{hr}$ of withdrawal of the drug (17:00 hr) during drug administration. Challenging with $2 \mathrm{mg} / \mathrm{kg}$ (s.c.) of levallorphan after feeding the rats on the low-dose and high-dose morphine-or codeine-admixed foods for 1, 3 and 6 weeks resulted in a greater weight loss rate in the high-dose group at each challenge. However, the rate of weight loss with the application of levallorphan did not tend to increase with a longer application of morphine. This phenomenon was also observed with the application of $5 \mathrm{mg} / \mathrm{kg}$ of levallorphan (s.c.): thus, the abstinence sign hardly varied with the dose of levallorphan. The codeine-dependent rats used in this experiment also did not vary significantly in the weight loss rate with the dose of levallorphan ( 2 or $5 \mathrm{mg} / \mathrm{kg}$, s.c.) nor was there any given correlation

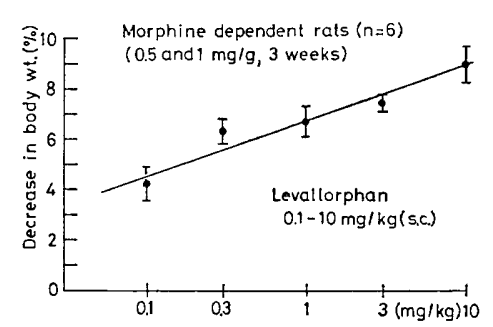

FIG. 1. Dose-response curve between the maximum weight loss rates and doses of levallorphan $(0.1-10.0 \mathrm{mg} / \mathrm{kg}$, s.c.) given to rats made morphine-dependent by the DAF method. The rats were fed a morphine-admixed food $(0.5-$ and $1-\mathrm{mg} / \mathrm{g}$ food; mean daily absolute intake of morphine, $50-60 \mathrm{mg} / \mathrm{kg}$ ) for 3 weeks. The weight loss rates were calculated with the challenge of levallorphan being $0 \%$.

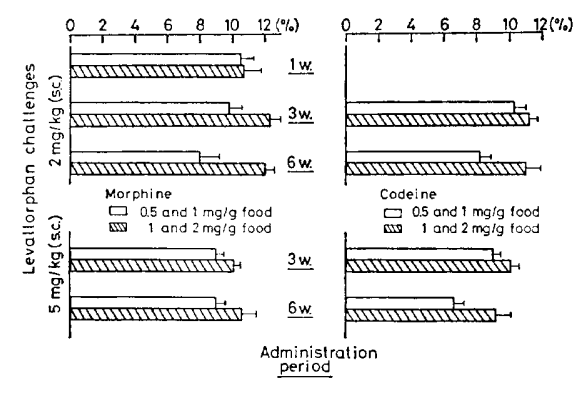

FIG. 2. Correlation between the doses or application periods of morphine or codeine and the abstinence signs induced by levallorphan (with the maximum weight loss rate as index). Morphine or codeine was given at $0.5-$ and $1-\mathrm{mg} / \mathrm{g}$ food (white column, with the mean intake of $50-60$ $\mathrm{mg} / \mathrm{kg} /$ day) and $1-$ and $2-\mathrm{mg} / \mathrm{g}$ food (shaded column, with the mean intake of 100-120 $\mathrm{mg} / \mathrm{kg} / \mathrm{day})$. The levallorphan challenge was made with 2 and $5 \mathrm{mg} / \mathrm{kg}$ (s.c.) at 1, 3 and 6 weeks (w. shown in the figure) of application of the above drug. Each group included 6 rats. 
between the periods of application of codeine (1, 3 and 6 weeks) and the weight loss rates with the application of levallorphan (Fig. 2). When the weight loss in the group on the lowdose morphine food and the group on the high-dose food at the respective stages of application were compared, the loss rate in the latter was greater and dose-dependent at each of 1,3 and 6 weeks. The maximum weight loss rates by challenging with $5 \mathrm{mg} / \mathrm{kg}$ of levallorphan to both groups at 3 and 6 weeks of application showed almost the same pattern of the weight loss rates as in the low-dose of levallorphan challenge. As a whole, decrease in body weight precipitated with levallorphan was dependent on the dose of morphine or codeine ingested, but not on the period of administration of either drug.

Experiment 3: Fig. 3 shows the maximum weight loss rate when levallorphan $(2 \mathrm{mg} /$ $\mathrm{kg}$, s.c.) was applied on the final application day at each of the gradually increased doses of

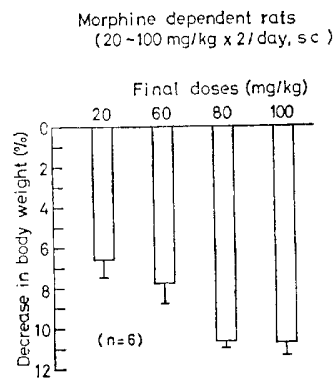

Fig. 3. Maximum weight loss rates by application of levallorphan in place of morphine on the final day $(17: 00 \mathrm{hr})$ at each of dose of morphine during the application of morphine in gradedly increased doses of $20-100 \mathrm{mg} / \mathrm{kg}$ (s.c.) twice a day (09:00 and 17:00 hr). Morphine was applied on the schedule that the initial dose of $20 \mathrm{mg} / \mathrm{kg}$ (s.c.) for each application was increased to $40,60,80$ and finally $100 \mathrm{mg} /$ $\mathrm{kg}$ at 7 day intervals. The weight loss rates were calculated with the challenge of levallorphan (at 17:00 hr) being 0\%.

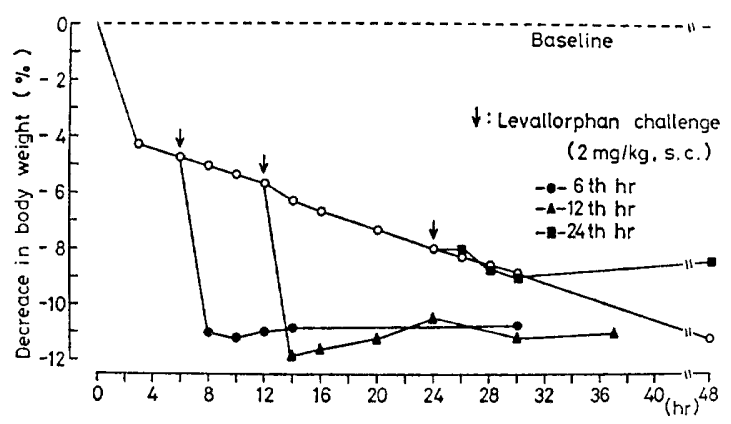

FIG. 4. Variations in body weight with the passage of time after application of levallorphan $(2 \mathrm{mg} / \mathrm{kg}$, s.c. $)$ only one at $6(-\mathbf{-}), 12(-\mathbf{\Delta}-)$ or $24(-\square) \mathrm{hr}$ of natural withdrawal (by replacing the morphine-admixed food with a normal food) from 3 of 4 groups of rats $(n=6)$ fed on a morphine-admixed food $(0.5-$ and $1-\mathrm{mg} / \mathrm{g}$ food) for 3 weeks. One group was placed under natural withdrawal without levallorphan challenge for $48 \mathrm{hr}(-\bigcirc-)$. The weight loss rates are plotted on the ordinate, with the body weight at levallorphan challenge being $0 \%$. 
morphine. No sooner had levallorphan been applied than morphine abstinence signs, e.g., soft feces, piloerection and hypothermia, and also losses in body weight occurred even in these animals treated with gradually increasing doses of morphine. The weight loss rates at the dosage stages were $5.7,6.7,10.7$ and $10.8 \%$ : thus, the weight loss rate tended to be greater with the higher dose of morphine, and even the challenge with levallorphan resulted in a weight loss and such correlated well with the given doses of morphine.

Experiment 4: Fig. 4 shows variations in body weight with application of levallorphan to the morphine-dependent rats at $0,6,12$ and $24 \mathrm{hr}$ of morphine withdrawal. The weight loss at six hr of natural withdrawal was $4.8 \%$; morphine abstinence signs were scarcely manifested at this stage; the maximum loss in body weight with the levallorphan challenge was $6.3 \%$. The weight loss rate due to natural withdrawal $12 \mathrm{hr}$ after the withdrawal was $5.5 \%$; when mild morphine abstinence signs, e.g., soft feces and piloerection were observed, and the weight loss with levallorphan at this stage, as in cases of weight loss with the levallorphan challenge at $0 \mathrm{hr}$ of withdrawal, reached a peak in $2-4 \mathrm{hr}$, with a loss rate of $6.0 \%$. The weight loss rate due to natural withdrawal at $24 \mathrm{hr}$ of withdrawal was $10.4 \%$, when nearly no weight loss occurred with levallorphan challenge (Fig. 4). No weight loss occurred with levallorphan challenge at $24 \mathrm{hr}$ and later stages of withdrawal.

Experiment 5: Fig. 5 shows variations in body weight with the three consecutive applications of levallorphan at $5 \mathrm{hr}$ intervals, after withdrawal of morphine to morphinedependent rats. A severe loss $(8.0 \%)$ in body weight occurred with the initial application of levallorphan; however, there were few signs of abstinence with the subsequent applications of levallorphan. After three consecutive applications of levallorphan, the animals tended to gain weight, despite the persistent weight loss in the group on natural withdrawal and these animals recovered body weight rapidly even to the level of only $1.5 \%$ loss $13 \mathrm{hr}$ later (at $24 \mathrm{hr}$ of morphine withdrawal).

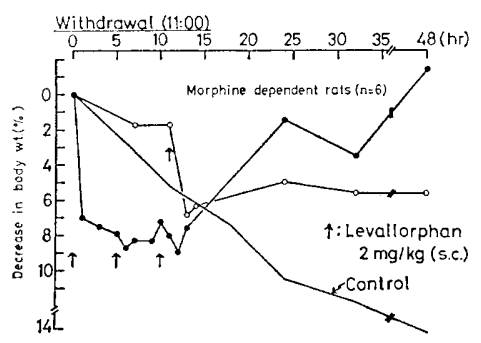

FIG. 5. Variations in body weight with one or three consecutive applications of levallorphan to 2 of 3 groups of rats $(n=6)$ fed on a morphine-admixed food (0.5and $1-\mathrm{mg} / \mathrm{g}$ food) for 3 weeks during a natural withdrawal period. One group was challenged with levallorphan $(2 \mathrm{mg} / \mathrm{kg}$, s.c. at a time) 3 times successively at 0,5 and $10 \mathrm{hr}$ of withdrawal (closed circles); the other group was challenged with levallorphan only at the 11th hr of withdrawal (open circles); and another group was under natural withdrawal for $48 \mathrm{hr}$ without levallorphan challenge (solid line). Variations in body weight are shown with the body weight at $0 \mathrm{hr}$ of withdrawal being $0 \%$. 


\section{DISCUSSION}

The method of evaluating the precipitation of abstinence signs in morphine- and codeinedependent rats by challenging with a narcotic antagonist was first comparatively studied in terms of the correlation between the doses and application periods of drugs that had already been observed in the morphine and codeine dependence tests described in a previous paper (8). The mode of antagonistic action of levallorphan in opiate-dependent rats was then studied in terms of the pattern of precipitation of abstinence signs by challenge of levallorphan at specified intervals to morphine- and codeine-dependent rats during natural withdrawal.

Quantitative studies of the antagonistic actions of narcotic antagonists to morphinetype drugs on the rodents have been done with the analgesic tests, Straub's phenomenon, respiratory depression, etc. as indicators $(5,9)$, but there are few reports on the quantitative evaluation of chronic morphine effects or dependence $(2-4,10)$. Wei and Loh (3) showed the dose-response relationship in the evolvement of weight loss rate with challenge of several doses of naloxone $(0.5-10 \mathrm{mg} / \mathrm{kg}$, s.c.) to rats made morphine-dependent by the morphine pellet implantation method. However, there is apparently no report on the agonistantagonist interaction with changes in the daily dose of morphine (often applied as one pellet) or in the application period of the drug. On the other hand, it is essential for the quantitative examination of physical dependence-producing capability to evaluate it from the viewpoints of frequency of application and doses and application period of the test drug; hence, it is also important even in the precipitation test of the abstinence signs with antagonists to evaluate the physical dependence liability from these viewpoints.

When the abstinence signs evolving on the challenge with several doses of levallorphan to the rats maintained morphine-dependent by the DAF method (at $0 \mathrm{hr}$ of withdrawal) were observed in terms of weight loss rate, it was apparent that $1-2 \mathrm{mg} / \mathrm{kg}$ of levallorphan (equivalent to $1 / 60-1 / 30$ the maintenance dose of morphine) was sufficient to antagonize $50-60 \mathrm{mg} / \mathrm{kg} /$ day morphine as the maintenance dose, and with a higher dose, there was a tendency toward a plateau formation. Also, in the animals given morphine in the same dose for the same length of time, a linear dose-response curve was evident within the dose range of $0.1-10.0 \mathrm{mg} / \mathrm{kg}$ of levallorphan (s.c.), this result being similar to that obtained in animals made morphine-dependent by the pellet implantation method (3). The mode of antagonistic action of levallorphan on the animals on two maintenance dose levels of morphine and codeine was investigated from the standpoint of maintenance doses and periods of application. The weight loss rate did not necessarily correlate with the severity of the dependence, irrespective of the doses of levallorphan ( 2 and $5 \mathrm{mg} / \mathrm{kg}$ ). This implies that the degree of abstinence signs induced by levallorphan should rather be considered no more than a qualitative assay. As described in previous papers $(8,11)$, in the morphine or codeine dependence-producing test, the weight loss during a natural withdrawal increased in magnitude at least during the first 7 weeks and such was dependent on the dose and application period of the drug. There are also data that severe abstinence signs evolve in morphine-dependent rats at $24-72 \mathrm{hr}$ of withdrawal (11). On the other hand, the severity 
of morphine abstinence signs induced by levallorphan became less intense with the passage of time after withdrawal. The reaction to the challenge with levallorphan in the course where the absinence signs due to natural withdrawal came to a maximum, i.e., at $24 \mathrm{hr}$ of withdrawal, showed that the abstinence signs were already hardly induced or enhanced. Abstinence signs, therefore, are apparently induced by levallorphan only in the presence of morphine, and these signs vary in severity with the time of application of levallorphan. This suggests that, in the test of physical dependence liability on rapidly metabolized drugs, the evaluation of dependence on the drugs may vary with the difference in the timing of application of the antagonist. From this finding, challenging morphine-dependent rats with antagonists without withdrawal of morphine (dependent state) makes it possible to clearly and accurately evaluate the severities of abstinence signs and also to make the test results reproducible.

When the morphine-dependent rats that exhibit a maximum weight loss at 24-48 hr after natural withdrawal, were challenged with levallorphan 3 times in succession at $5 \mathrm{hr}$ intervals after morphine withdrawal, the abstinence signs were hardly precipitated or enhanced by the second and subsequent applications of levallorphan, and the animals rapidly recovered from withdrawal signs (being completely recovered as early as at $24 \mathrm{hr}$ from morphine withdrawal). This implies that the use of the long acting antagonist, naltrexone (12-14) for patients dependent on opiate-type drugs will give rise to the early recovery from abstinence symptoms.

In conclusion, the severities of abstinence signs induced by levallorphan in the tests of physical dependence on opiate-like drugs are correlated with the applied doses of the test drugs (dependence maintenance doses), but vary little with the length of application period of the test drug. Also, because the severities of abstinence signs varied with the interval of challenge with levallorphan after the final application of morphine, challenge with levallorphan should be made at $0 \mathrm{hr}$ of withdrawal (with the animals in a morphine-dependent and non-withdrawn state) for the purpose of obtaining qualitative and reproducible results.

\section{REFERENCES}

1) Hosoya, E.: Screening of dependence liability of drugs using rats. Methods in Narcotic Research, Edited by Ehrenpreis, S. AND NeIdle, A., p. 261-291, Marcel Dekker, Inc. (1975)

2) WAY, E.L., LoH, H.H. AND Shen, F.H.: Simultaneous quantitative assessment of morphine tolerance and physical dependence. J. Pharmacol. exp. Ther. 167, 1-8 (1969)

3) WEI, E. AND LOH, J.H.: Quantitative aspects of precipitated abstinence in morphine-dependent rats. J. Pharmacol. exp. Ther. 184, 398-403 (1973)

4) WEI, E.: Assessment of precipitated abstinence in morphine-dependent rats. Psychopharmacology 28, 35-44 (1973)

5) Martin, W.R.: Opioid antagonists. Pharmacol. Rev. 19, 463-521 (1967)

6) Dewey, W.L.: Narcotic-antagonist assay procedures in dogs. Narcotic Antagonists, Edited by Braude, M.C., Harris, L.S., May, E.L., Smith, J.P. and Villarreal, J.E., p. 263272, Raven Press, New York (1974)

7) Villarreal, H.E. ANd Karbowski, M.G.: The action of narcotic antagonists in morphinedependent rhesus monkeys. Narcotic Antagonists, Edited by Braude, M.C., Harris, L.S., May, E.L., Smith, J.P. ANd Villarreal, J.E., p. 273-289, Raven Press, 
New York (1974)

8) Yanaura, S., Tagashira, E. and Suzuki, T.: Physical dependence on morphine, phenobarbital and diazepam in rats by drug-admixed food ingestion. Japan. J. Pharmacol. 25, 453-463 (1975)

9) PIf.rson, A.K.: Assays for narcotic activity in rodents. Narcotic Antagonists, Edited by Braude, M.C., Harris, L.S., May, E.L., Smith, J.P. and Villarreal, J.E., p. 245261, Raven Press, New York (1974)

10) Cicero, T.J. ANd Meyer, E.R.: Morphine pellet implantation in rats; quantitative assessment of tolerance and dependence. J. Pharmacol. exp. Ther. 184, 404-408 (1973)

11) Yanaura, S., Tagashira, E. And Izumi, T.: The drug-admixed food ingestion method for physical dependence test in rats. Japan. J. Pharmacol. 25, Supp. 118P (1975)

12) Zaks, A., Jones, T., Fink, M. and Freedman, A.M.: Naloxone treatment of opiate dependence. J. Am. med. Ass. 215, 2108-2110 (1971)

13) Martin, W.R., JaSInSKI, D.R. AND ManSKY, P.A.: Naltrexone, an antagonist for the treatment of heroin dependence. Arch. gen. Psychiat. 28, 784-791 (1973)

14) Blumberg, H. and Dayton, H.B.: Naloxone, naltrexone and related noroxymorphones. Narcotic Antagonists, Edited by Braude, M.C., Harris, L.S., May, E.L., Smith, J.P. and Villarkeal, J.E., p. 33-43, Raven Press, New York (1974) 